\title{
Commodity and Waste as National Allegory in Recent South African and Post-Soviet Fiction
}

\author{
Alla Ivanchikova \\ University of Alaska Fairbanks
}

Follow this and additional works at: https://docs.lib.purdue.edu/clcweb

Dedicated to the dissemination of scholarly and professional information, Purdue University Press selects, develops, and distributes quality resources in several key subject areas for which its parent university is famous, including business, technology, health, veterinary medicine, and other selected disciplines in the humanities and sciences.

CLCWeb: Comparative Literature and Culture, the peer-reviewed, full-text, and open-access learned journal in the humanities and social sciences, publishes new scholarship following tenets of the discipline of comparative literature and the field of cultural studies designated as "comparative cultural studies." Publications in the journal are indexed in the Annual Bibliography of English Language and Literature (Chadwyck-Healey), the Arts and Humanities Citation Index (Thomson Reuters ISI), the Humanities Index (Wilson), Humanities International Complete (EBSCO), the International Bibliography of the Modern Language Association of America, and Scopus (Elsevier). The journal is affiliated with the Purdue University Press monograph series of Books in Comparative Cultural Studies. Contact: <clcweb@purdue.edu>

\section{Recommended Citation}

Ivanchikova, Alla. "Commodity and Waste as National Allegory in Recent South African and Post-Soviet Fiction." CLCWeb: Comparative Literature and Culture 13.4 (2011): <https://doi.org/10.7771/1481-4374.1723>

This text has been double-blind peer reviewed by $2+1$ experts in the field.

The above text, published by Purdue University Press @Purdue University, has been downloaded 690 times as of $11 /$ $07 / 19$.

This document has been made available through Purdue e-Pubs, a service of the Purdue University Libraries. Please contact epubs@purdue.edu for additional information.

This is an Open Access journal. This means that it uses a funding model that does not charge readers or their institutions for access. Readers may freely read, download, copy, distribute, print, search, or link to the full texts of articles. This journal is covered under the CC BY-NC-ND license. 


\section{PURDUE}

$\bar{U}$ N I V E R S I T Y UNIVERSITY PRESS <http://www.thepress.purdue.edu>

\section{CLCWeb: Comparative Literature and Culture}

ISSN 1481-4374 <http://docs.lib.purdue.edu/clcweb> Purdue University Press (C)Purdue University

CLCWeb: Comparative Literature and Culture, the peer-reviewed, full-text, and open-access learned journal in the humanities and social sciences, publishes new scholarship following tenets of the discipline of comparative literature and the field of cultural studies designated as "comparative cultural studies." In addition to the publication of articles, the journal publishes review articles of scholarly books and publishes research material in its Library Series. Publications in the journal are indexed in the Annual Bibliography of English Language and Literature (Chadwyck-Healey), the Arts and Humanities Citation Index (Thomson Reuters ISI), the Humanities Index (Wilson), Humanities International Complete (EBSCO), the International Bibliography of the Modern Language Association of America, and Scopus (Elsevier). The journal is affiliated with the Purdue University Press monograph series of Books in Comparative Cultural Studies. Contact: <clcweb@purdue.edu>

\section{Volume 13 Issue 4 (December 2011) Article 7 Alla Ivanchikova, \\ "Commodity and Waste as National Allegory in Recent South African and Post-Soviet Fiction" <http://docs.lib.purdue.edu/clcweb/vol13/iss4/7>}

Contents of CLCWeb: Comparative Literature and Culture 13.4 (2011)

<http://docs.lib.purdue.edu/clcweb/vol13/iss4/>

Abstract: In her article "Commodity and Waste as National Allegory in Recent South African and PostSoviet Fiction" Alla Ivanchikova analyzes the issue of commodity in its relation to identity. The article contains a reading of two novels: The Quiet Violence of Dreams by K. Sello Duiker and Dukhless. Povest o nenastoiaschem cheloveke (Douh-Less: The Tale of an Unreal Person) by Sergey Minaev. Rapid political changes, both in South Africa and the former Soviet Bloc were accompanied both by rapid changes in the practices of consumption and also by often inconsistent cultural efforts to establish the meaning of these practices. Ivanchikova argues that in contemporary South African and postsocialist Russian culture there is an attempt to reconstitute identity through the discourse of commodity consumption and self-sale. Further, Ivanchikova examines the contradictions of consumption and self-sale in the "third world," issues of Western privilege and power, and the notion of prostitution as a symbol of cultural anxiety about a nation's future. 
Alla Ivanchikova,

"Commodity and Waste as National Allegory in Recent South African and Post-Soviet Fiction"

page 2 of 9

CLCWeb: Comparative Literature and Culture 13.4 (2011): <http://docs.lib.purdue.edu/clcweb/vol13/iss4/7>

\section{Alla IVANCHIKOVA}

\section{Commodity and Waste as National Allegory in Recent South African and Post-Soviet Fiction}

Within recent decades, writers from the former Soviet Union and from South Africa have faced social transformation of epic proportions including regime change and the end of state sanctioned censorship and persecution. However, the sense of excitement that accompanied change was replaced by a sense of disillusionment and crisis. Despite the fact that being "after communism" or "after apartheid" initially meant commitment to equal opportunity and freedom for all, new forms of inequality and exploitation emerged. These countries' efforts to achieve greater economic liberalization and democratization were hindered both by internal factors such as weak and ineffective state, economic disparity, and social tensions, as well as external factors such as the process of globalization. The ensuing multidimentional crisis in both post-apartheid South Africa and post-socialist Russia included a crisis of ideology, "a vacuum of purpose and agenda in the wake of the collapse of pre-independence transformational projects" (Bessinger and Young 4). In my article, I address the ways in which this sense of ideological vacuum is expressed in some of the recent examples of post-socialist Russian and postapartheid South African fiction. Despite the fact that the social relevance of literature, its role as an instrument of political struggle in the post-apartheid and post-socialist era has diminished, it remains an important tool for articulating the meaning of the "post-" regime condition and also, to use the words of a former South African justice minister Dullah Omar, serves as an important purpose of articulating and "healing the wounds of the past" (Omar qtd. in Jones 116).

Multiple connections and similarities between the two literary traditions are yet to be explored. Rob Nixon, for instance, writes of the "intuitive empathy" between South African writers and former Soviet dissident authors who found disillusionment in their own victory: "the concerns that South African writers have voiced echo well beyond their shores, particularly to the former Soviet Union and the countries of the Warsaw Pact, where democratic victories have also brought uncertain returns. In many of these countries, expanded social freedoms have done little to erase poverty; in some of them it has worsened, as has joblessness" (64). Perhaps one of the most important aspects of the social transformation that occurred in both South Africa and in former Soviet Russia is the rapid integration of marginalized and isolated economies into transnational market economy which was experienced as a new form of colonialism. The issue of commodity is central when one tries to understand the nature of cultural transformations and that occurred in both regions. Hyperinflation of commodity's symbolic status was frequently coupled with fierce resistance and rejection of consumerist ideology. Although consumerist society has, to put it in Rachel Bowlby's words, "the aura of enfranchisement," this enfranchisement affected various population groups unevenly (26; see also Oushakine).

My objective in this article is the issue of commodity in its relation to identity, which I explore by offering a reading of two novels: The Quiet Violence of Dreams by K. Sello Duiker and Dukhless. Povest o nenastoiaschem cheloveke (Douh-Less: The Tale of an Unreal Person) by Sergey Minaev (the title of the novel can be translated as Soul-Less). My argument does not depend on the notion of a stable identity; on the contrary, I understand identities as imaginary processes of identification whereby new identities crystallize around new economic and cultural practices. The rhetoric of consumption plays a central role in the process of identity formation (personal and collective) in both novels. In fact, the authors explicitly suggest that contemporary South African and post-socialist Russia transitional identities (perhaps in a climate of vacuum of any other purpose and agenda) try to reconstitute themselves through the discourse of commodity consumption and self-sale. What we see there is a hyperinflation of one's commodity status coupled with profound anxiety about this process. Commodity presents an important promise while also posing a threat. I analyze how the two writers explore the paradoxes of consumerism from the perspective of an ultimate commodity (a prostitute) in Duiker's novel and from the perspective of an ultimate consumer (in Minaev's novel). It is also significant that in both novels the protagonists eventually exit the realm of circulation as commodities and are presented as "trash" or waste. Instead of realizing their full potential as enfranchised consumers in a transnational market economy, they become what I call "trash citizens" - discovering that waste is, inevitably, the dialectical counterpart of every commodity. Both novels could be read as allegorical in 
Alla Ivanchikova,

regards to post-socialist Russian and post-apartheid South African national identity. The hyperinflation of commodity status in both novels and the resulting rhetoric of disillusionment is a response to the ideological vacuum and uncertainty that defines the post-socialist or post-apartheid condition - a situation that consumerist ideology promises to resolve, but fails. In both novels, the characters' initial belief in the omnipotent equalizing powers of commodity capitalism turns into what I call "intoxication" - a neurotic identification with the commodity's value of exchange.

K. Sello Duiker is an important new South African writer, known in the fields of postcolonial theory for his two ambitious and controversial novels: Thirty Cents and The Quiet Violence of Dreams. Duiker sparked a wave of reviews and tributes after his tragic death in 2005 when he took his own life at just twenty-seven. Published in 2001, The Quiet Violence of Dreams is a powerful example of contemporary South African writing: central to the narrative are the protagonist's quest for identity, coming to terms with his queer sexuality, the issues of dealing with sexual abuse and mental illness and all of which occurs in the midst of the whirlpool of interracial problems in a post-apartheid state. In The Quiet Violence of Dreams, the reader is transported into a complex, disturbing space, and haunted by the recent history of racism and violence. Located in the city of Cape Town, the world described in the novel is a fractured world, where cultures are in conflict but are forced to coexist with each other by virtue of their shared history. The city of the novel is a porous and blotched space where the fabric of the first world is perforated with enclaves of the third and fourth worlds. These enclaves inevitably spill into the carefully protected territory of the first-world capitalistic "bliss," damaging the coherence of the latter and threatening its self-definition. Tshepo, the protagonist and at times the narrator of the novel, is a young cosmopolitan Black gay man, whose identity is situated along South African class lines: he is depicted as neither a possessor of capital nor dispossessed, coming from a middle class background yet struggling to make ends meet by taking odd jobs around town. Initially, Tshepo is depicted as a hopeless fashion victim, a careless consumer, a connoisseur of consumerist culture, uncritically participating in this culture's obsession with novelty, fashion, brands, and prices. Young and good-looking, he believes that Cape Town as a growing metropolis that aspires to the "the next best thing," a place where the language of race has been superseded by a superior and universal culture: "when you go out in some places in Cape Town no one really cares if you're black and that your mother sent you to a private school so you could speak well. No one cares if you're white and that your father abuses his colleagues at work and calls them kaffirs at home. People only care if you can dance and that you look good. They care if you're wearing Soviet jeans with an expensive Gucci shirt and that you have a cute ass ... They want to see you wearing Diesel jeans with a retro shirt and Nike tackies" (34). Garish cosmopolitanism of his city as a newly emerging world market seems to offer a quick solution to the country's problems: the perpetual novelty of commodities initiates a cultural amnesia erasing the memory of the troublesome decades of racism and discrimination. The protagonist of the novel finds himself seduced into this new world and seems to disappear in it without further reservation: "designer labels are the new Esperanto. Dolce e Gabbana kicks more ass than any bill of rights" (35).

The novel exposes a perpetual darker side to Tshepo's life, the side that he himself seeks to suppress and forget. He suffers from a psychiatric condition: occasionally, he hears voices and sees ghosts, and after an acute psychotic episode he has to spend some time at a psychiatric hospital. Tshepo's psychosis is presented as the consequence of a childhood trauma where his mother gets raped and killed by five African men. Tshepo himself was raped during this event. Burdened by traumatic memories, he finds himself roaming around town, feeling haunted, bewitched and scared: "I've walked the city drugged into somnambulism. I've walked till my feet ached with blisters, till I've yearned for sleep as if it were my best friend, my only friend. Sometimes I walk into the city's bowels where they plant the evil; unspeakable evil that keeps us gleefully oppressed. It is under bridges, near the Good Hope Centre, at the Khayelitsha train stop, in town and in libraries. That is where some of the evil lies in the form of rotting filth and pollution" (92-93). Initially, these two aspects of Tshepo's life seem separate and disjointed. His madness perforates and disrupts his routine activities as a foreign force, unexplained and unaccounted for, projected into "the bowels of the city" as evil, pollution and filth. While commodities have the power to abolish divisions through its equalizing quality, filth has the power to abolish differences through contamination and pollution. In Tshepo's imagination, the city of Cape Town appears as a marketplace, a frictionless passage through which commodities move 
Alla Ivanchikova,

freely, forever readjusting their looks in respect to the prospective buyer. Since shopping is often a self-conscious prerequisite of self-selling, we see the merging of the consumer with the commodity early in the novel. Tshepo's vision of consumerism implies that each person must turn himself or herself into a skillfully crafted package for sale, one that appears unique despite the fact that it is assembled from mass-produced pieces - Diesel jeans, Armani shirts, Nike sneakers, and so on.

The best commodity acquires the highest degree of mobility, as it is desired by the highest number of buyers and is thus welcome in the highest number of establishments. Social mobility is envisioned as a function of commodification; just as Karl Marx reminds us, the commodity has to constantly move, change hands (131). Tshepo's obsession with self-marketing through fashion and brand names turns into a real sale when, unable to find work, he takes a full-time position at an upscale massage parlour called "Steamy Windows." The transition from self-advertising in clubs to prostitution is seamless; after all, "acts of display and voyeurism are only a socially sanctioned version of the disreputable transaction of prostitution" (Parsons 53). Tshepo's preparing for work is very similar to his preparing for a trip to a club: "in the afternoon, I start thinking about work. ... In the medicine cabinet I see some platinum blond dye ... Remember, anything you can use to your advantage helps in this industry, I recall Shaun's words. Why not? I say as I read the instructions, my mind racing ahead with the exotic look I'm hoping to achieve" (229). Consumerism, having access to "nice things" in The Quiet Violence of Dreams translates into personal desirability, turning into an object on display and, ultimately, an object for sale. Zigmunt Bauman explains this phantasmatic identification of the consumer with the commodity: "in the society of consumers no one can become a subject without first turning into commodity, and no one can keep his or her subjectness secure without perpetually resuscitating, resurrecting and replenishing the capacities expected and required of a sellable commodity" (12). Becoming a subject in a consumerist society means first turning into an object - identifying with the commodity. Commodities hold an aura of emancipation, promising equality, liberation, power, and desirability. A consumer is seduced to the point of being absorbed into and intoxicated by the commodity.

Modernist theories of consumption are useful for grasping this uneasy, contradictory relation between a consumer and a commodity. In his theory elaborated in the Arcades Project Walter Benjamin suggests that this relation seems to fluctuate on the continuum between two opposite situations: the consumer's "objectification" and voyeurism in regards to the commodity and his "identification" and empathy with the commodity: "empathy with the commodity is fundamentally empathy with exchange value itself" (448). The concept of empathy invoked in the statement above implies the consumer's psychic identification with the commodity, or rather with its particular aspect, its exchange value. Further writings of Benjamin reveal that the key to the paradox of the subject's relation to the commodity is found in the paradox of the commodity itself. He draws upon the analysis of the commodity in Capital, where Marx demonstrates that there is an inner conflict within any commodity, a tension, an antagonism between its use value and its exchange value. This conflict also represents itself as a tension between the commodity's particular nature and its abstract universality as part of the process of exchange. Exchange-value, or the very exchangeability of the commodity, according to Marx, stands in a direct relation to the promise of universality and equality as ideological values that every commodity implicitly contains within itself. Marx further suggests that exchange value itself signifies both universal connectivity and alienation as social relations. These contradictions are dialectical oppositions and signify the commodity's historicity and its inherent internal instability.

This antagonism within the commodity is further theorized by Benjamin through his concept of empathy. Empathy is presented as a consumer's unconscious response to the sight of the commodity, a psychic operation of identification with the universality of the commodity represented in its exchange value. This identification with the commodity's universal exchangeability is confronted by its dialectical opposite, that is, alienation represented in the commodity's price: "It is only as commodity that the thing has the effect of alienating human beings from one another. It produces this effect through its price. What is decisive is the empathy with the exchange value of the commodity, with its equalizing substrate ... such absolute equality is the graying background against which the gaudy colors of sensation stand out" (386). As the commodity and its contradictions enter the psychic circulation process through the act of identification, the subject becomes a victim of intoxication with the commodity by simultaneously identifying with its universality while, unconsciously, experiencing alienation repre- 
Alla Ivanchikova,

sented in its price. At this point, commodity becomes an obsession: "in the psychic economy, the mass-produced article appears as obsessional idea. It answers to no natural need. The neurotic is compelled to channel it violently among the ideas within the natural circulation process" (340).

As a mass-produced item, the commodity opens up a dream-like possibility of communion with the crowd, suggesting "the possibility of a mythical communication with the masses" (Benjamin qtd. in Buck-Morss 190). The Quiet Violence of Dreams provides a vivid example of the subject's identification with the universal, equalizing aspect of commodity that leads to such "intoxication": "you must aspire for universality of CK One and still you must be willing to absorb more until all you can see at the dance floor are people packaged in a way that brings fire to your loins. Until music becomes the only thing that's important and dancing becomes the only thing separating you from another person ... These are the things that define the Club culture in Cape Town, not racial politics" (35). This "universality" somewhat self-ironically referred to as the "universality of CK One" replaces the old-fashioned partiality of "black and white": "color becomes secondary to the person you present. They want to say you're cool not that you're black or white" (35). In these paragraphs, the commodity's universality (represented by its exchange value) is emphasized while its nature as alienation (its price) is obscured. Similar to Benjamin's view, an excessive identification with this universal aspect of the commodity leads to intoxication by commodities. The disappearance of individual identities in the universal commodity status creates the ecstasy of the mythic communion with the crowd, dissolving the dividing lines between individuals. This communion with the crowd is a sexualized experience; intoxication abolishes differences without abolishing desire, "until all you can see ... are people packaged in a way that brings fire to your loins" (The Quiet 35).

The hyperinflation of commodity status in The Quiet Violence of Dreams is neither coincidental nor unique. Minaev describes a few days from the life of a young Moscovite who maintains the same uncritical belief in the transcendent, magical power of labels and brands. The unnamed protagonist and narrator of the novel is presented as a successful corporate manager in a multinational food company by day and as a ruthless clubber, a metropolitan dandy, and an extravagant consumer by night. A proud user of a corporate car and a corporate credit card, aiming to be recognized as a valuable member of the lunar world of exclusive Moscow nightlife, he excels in the art of elegant and glorious expenditure. The narrator's high social status in the novel is established through his capacity to spend and overspend money publicly - in overpriced boutiques, in coveted exclusive night clubs, and in prestigious restaurants where "one has to be seen." The novel has not been translated into English; in the absence of a conventional translation, I am offering my own translation of the title and all the passages I quote in this article. The original title of the novel is a hybrid word (Дyx-Less) with the first half written in Cyrillic characters and the second part in Latin characters. The title can be translated as Dukhless; however, some of the original meaning is lost in this translation. In Soul-Less, a "corporate dandy" is depicted as a messenger, a translator, an ambassador of capitalism flaunting his easy access to commodities - exclusive club memberships, designer clothes - in post-socialist Russia, still, in many ways defined by the Soviet legacy. The narrator of Dukhless just as the narrator of The Quiet Violence of Dreams, envisions the language of labels as an Esperanto - a universal "language of price" that ensures the protagonist's membership in the globalized world of progressive consumers. The protagonist cynically boasts his proficiency in the language of the labels by evaluating members of "the crowd" in a popular night club: "the club is full of people but the selection is quite mediocre. Two dozens of clerks acting out in front of the girls. The clerks have more lust than money and they are trying their best to prove to everyone around that they are young oligarchs. A couple of real oligarchs who have more money than lust and who try to resemble the bohemians (with faded $t$-shirts, ripped jeans, etc). A dozen real bohemians, real hipsters, who have neither money nor lust. A dozen rich kids who have more money than the hipsters but less than the clerks" (258).

In both Duiker's and Minaev's novels, the commodity's main role is to disempower the past, to render it impotent, outdated, and obsolete. Both protagonists are presented as ahead of everyone else, and also as most forgetful of their origins. The tyranny of the "new" expressed through the perpetual novelty of commodities is offered as a quick solution to the problems associated with the collective national past. In The Quiet Violence of Dreams, the aspect of universality represented by the commodities' exchange value promises a quick fix for the decades of inequality and racism: "It does not matter if you are black or white." In Minaev's narrative, commodities' novelty, or "glamour," eclip- 
Alla Ivanchikova,

ses soviet history completely, rendering it dull, bleak, and plain passé. The protagonist calls attention to his Westernized style and taste as opposed to what he calls sovok - a derogatory term that equates "soviet" with "retrograde," "outmoded," and "irrelevant." In addition to being a slang term signifying all things Soviet, sovok is also a standard Russian word for "dustpan" and thus has strong connotations with debris and trash. The rejection of sovok has thus the significance of disidentifying with objects devoid of exchange value. On the contrary, the protagonist's espousal of labels and brands exemplifies his desire to secure membership in the globalized community of consumers. Mostly of foreign origin, these brands are a colonial language he is desperately trying to learn. Soviet legacy is acceptable only when it is neutralized, when translated into the language of commodities, and when its links to surmounted history are severed. Café "USSR," a popular destination, serves an example of such neutralizing translation:"[Café] 'USSR' ... is made for those who do not remember the $80 \mathrm{~s}$... Such a place would look very 'Soviet' in New York or in London. Red neon letters, red turtlenecks on waiters, red comic book prints on the walls, vodka 'Smirnoff' and 'Absolute' in the bar and the attractiveness of words such as 'USSR,' 'K.G.B.,' or 'Red Army.' Such glamorous sovok with staff members dressed as KGB agents" (238).

Cafe "USSR" is fashionable because it is presented as an empty signifier: void or meaning and delocalized. In other words, Soviet history is acceptable only as "glamour" when fully absorbed into market economy and incorporated as a corporate style. The key term in the narrator's vocabulary is "the crowd" (tusovka). Contrary to the negatively connotated sovok, "the crowd" is a word invested with positive meaning. "The crowd" provides the public space, the stage for the acts of expenditure, constantly judging, evaluating, and sifting out its members. To be accepted by "the crowd" you have to share the same strict code - the code of labels: "to buy magazines that fit the size of a woman's purse (the same magazine will tell you where to buy the purse). To eat in restaurants called by one word (it's easier to remember). The main thing is - not to exit the common rhythm. Be part of the crowd. Be more simple. Leave space in your head for relevant information you will see in tonight's commercials on Fashion TV. Forget about everything else. And then your life will start to resemble a restaurant menu and you can choose what you like. Life-length menu of pleasures - isn't it Paradise? Can you resist something like this?" (134). Despite the fact that the narrator resents "the crowd" and refers to its members privately as "zombies" thus underscoring the emptiness of all interactions conditioned by its membership, he agrees that it is "the only system of coordinates and a compass for detecting your location" (135). In fact, the emptiness of these interactions is itself part of the code and a prerequisite for enjoyment as it allows for smooth and effortless circulation of messages without meaning. As in Duiker's novel, in Dukhless the power to consume, and consume excessively is firmly established as a direct result of self-sale. The protagonist describes himself and other corporate managers as expensive prostitutes who sell their soul and body to the company in exchange for money and purchasing power outside the company walls: "Because I am a professional hooker, I provide a wide range of services" (30). References to prostitution are numerous in the novel and the motif of prostitution is used to describe all social relations, from relationships at work to gender relations: "in 'Vogue Café' as in any other fashionable café in Moscow, there are many prostitutes pretending to be honest metropolitan women and there are many honest metropolitan women for some reason pretending to be prostitutes. The difference between the former and the latter is completely incomprehensible to me" (15).

Self-selling is defined as a prerequisite of shopping and envisioned as a universal activity. In the world of commodities, the only thing that distinguishes individuals from one another is the price. The act of spending, even more so, reckless and extravagant overspending, is seen as the highest form of enfranchisement. Becoming a commodity - a person whose body and soul is for sale - is in the novel a necessary prerequisite to becoming an ultimate consumer.

The protagonist's "empathy" or identification with the prostitute, and the constant oscillation between consumption and self-selling is experienced as intoxication - a process defined by its instability. The protagonist fluctuates between ruthless pursuit of the commodities and the utter and complete exhaustion that follows such pursuit. In other words, this identification cannot be sustained. Since the purpose of consumption is ecstatic merging with the crowd and entails temporary identity loss, being overwhelmed with commodities and circulation requires an escape in which the unity of subjectivity is reconstituted and restored after the experience of ecstatic splitting ("I am all these 
Alla Ivanchikova,

things at once!"). Metaphors of trash and waste serve the purpose of providing escape. The theme of consumption in the novel is thus tightly intertwined with the theme of physical intoxication, mental exhaustion, and waste. The narrative is structured around the protagonist aggressively consuming taking into his body - drugs, alcohol, cigarettes, food, women - which results in intoxication and passing out. It becomes clear that the protagonist consumes in order to be consumed, that is, wasted, literally. After many nights of excessive drinking and drug usage, the protagonist is passed out on a suburban train that takes him away from the city, to a no-name train station.

Still in a drunken haze, he finds himself walking away from the station towards the wilderness. The landscape is a typical Russian post-socialist province - an unpaved road follows the train tracks, small houses-shacks are seen from time to time. The houses disappear and the road takes the narrator into a forest where he stops to rest. Instead of offering a description of an idyllic pastoral landscape, Minaev describes that "a clearing in the forest that exhibits all the signs of Russian people's love of nature - empty beer bottles, cigarette butts, a couple of empty tin cans ... A rat carcass crowns that techno-still life. The rat was lying in a weird, unnatural position. Like a tiger preparing to jump up from the ground. The eyes half shut, the mouth open ... I drop my cigarette and continue walking ... As I make my way back to the train tracks, I see two dogs coming out of the dusk into the clearing. 'Bon appetite,' I wish them silently" (337-38). The novel ends with the scene featuring the protagonist meeting the sunrise, lying on an abandoned railway bridge, alone. He has lost his wallet, his watch, his cell phone, and he has nothing else left to consume: even the cigarettes are finished. In a symbolic and theatrical gesture, he throws the empty cigarette pack down and watches it fall into the water. The ending remains ambiguous as it is unclear whether the protagonist dies or will continue living. It makes no difference as he disappears as a symbolic (consuming) subject and becomes part of the landscape of waste. Importantly, the narrator calls himself a member of a "wasted generation" and dedicates his novel to the generation born in 1970-1976 - whose future seemed "so promising, so bright" and whose life were so "elegantly wasted" (282).

Minaev's novel depicts the "post-socialist" society as an ideological wasteland. "The wasted generation" of 1970-1976 is a discursive construction that the author uses to explicitly interpellate members of the audience most affected by the transition from socialism to capitalism. Allegorically, this generation (and the nation) is imagined as a corporate executive - a high class prostitute - working for a transnational corporation, and liking it. Unlearning the communist discourse with its focus on the future, this generation is scrambling to learn the code of commodities with its focus on the "now." No longer a significant player, but not completely enslaved either, Russia is depicted in her desire to "fit in" with the crowd of "consumers," deprived of any ideological agenda or a higher purpose of her own. Predictably, in both novels the protagonists turn out to be "trash citizens": after a brief period of circulation as commodities within the transnational economy, they discover that waste is, inevitably, the counterpart of every commodity. In Minaev's novel, the consequences of aggressive consumption lead to intoxication and require an escape to the wilderness, away from civilization, which leads, potentially, to the subject's annihilation. In Duiker's novel, the consequences and contradictions of commodification are more subtle, and the novel leaves more space for individual reflection and negotiation of one's status as a commodity. By becoming a hustler, Tshepo gains a behind-the-curtains view of what Jones calls "racial capitalism": despite the change in the political discourse, the uneven distribution of wealth is carried over into the new South African society (see Jones 126). Instead of the empowerment he was hoping for, Tshepo finds himself disillusioned. Even the camaraderie of the commodities in the parlour is burdened with racism and inequality. After all, "commodities can only enter into relationship under the watchful eyes of their 'guardians'" (Irigaray 196). One of the members reminds Tshepo that "Steamy Windows" is a business, and his position there is based on profit rather than friendship: "'don't get carried away. It's nice that we're all friendly and everything. I mean, I believe in the brotherhood, too. But who's pushing all the buttons? Who's got all the power? Who decides who stays and who leaves?' ... 'Shaun, white people,' I admit" (346).

The novel offers a critique of Tshepo's wish to make the commodity his home; as he becomes progressively disillusioned with his job, he finds himself uncontrollably drawn to the marginal spaces of the city: townships, ghettoes and slums. In the novel's final chapters, the representation of Cape Town changes dramatically. What was previously described as a cosmopolitan paradise now presents itself as a segregated, fractured, dilapidated city. Images of boutiques and cafes are replaced with the 
Alla Ivanchikova,

images of rot and decay. Duiker describes Cape Town as "a whirlpool of color. In the center it is lily white. On the edges the other colors gather like froth and dregs" (344). The geography of the city, with its stark racial boundaries, reveals the truth behind the ideology of equality, universality, and hybrid culture. The capitalist promise, Tshepo realizes, is valid only for the "lily white" center, but never for the "edges," where "haunting" is much more than just a metaphor. In the slums, the language of money fails as there are no commodities that compete with each other in terms of their desirability; there are stark needs that have to be satisfied, even if by refuse: "the filth is inescapable. Every wire mesh fence I see is plastered with plastic bags. Buy and dump, that is the message. After a while the pollution becomes the language, like a strange installation in a gallery that spreads across the township. You can see who is better off by the filth, the endless plastic bags that fly around" (434). If the White neighborhoods speak the language of commodities, in the townships, it is the refuse. Being itself a refuse of the center, "froth and dregs" washed out to the margins, the slum collects refuse and refuses to dispose of it, offering it for endless circulation. The margins literally feed off the refuse, carving it into digestible pieces; perpetually reprocess the old and the dead, rather than chasing after the novelty of the commodity: "in one street corner, a group of women with huge enamel dishes that look like small bath tubs are gathered round a horse that must have dropped dead there. They wield long and dangerous looking knives, carving up the horse, passing huge chunks of meat among themselves. I watch them arguing about its entrails" (428). Endlessly trapping, regurgitating, and recycling trash and waste, the townships are the greatest storage of the past, where nothing is disposed of, nothing superseded, or forgotten. The old and the new are forced to cohabitate, unwillingly, side by side. The time slows down, stops. In the slums, Tshepo becomes intoxicated once again: this time by identifying with filth and refuse rather than with commodities. He is overcome by the stark realization that he himself, along with the residents of the township, is the refuse of history. Commodification does not spread that far south, that far beyond the line drawn by one's race, class, one's origin. Ghettoes and townships are resistant to commodification: they are precapitalist, empoverished, strikingly pre-modern.

Both novels expose the contradictions of commodity fetishism when it extends itself into the world's margins, bowels, and slums - contradictions that cannot be easily, if ever, surpassed. The first world seeks to spread out its ideology, without spreading out its privilege; it tries to substitute the imaginary universality for the differences unsurpassable in real life, and fails. Commodities present themselves as a common language, offering a semblance of universality, a utopian vision of the equality and "brotherhood" or "sisterhood" of commodities, without extending the means of survival, let alone privilege, to the ones they seek to seduce. The language of refuse in the novels replaces the language of commodities as more universal; as it is the majority of the world's population that find themselves excluded, wasted, recycled in the neo-Malthusian commercial "paradise." The protagonists of both novels are, indisputably, victims of these contradictions, but they are also capitalism's inner critics. While in Dukhless trash is deprived of positive meaning and thus leads to the subject's selfannihilation, in Duiker's novel trash presents a possibility. Duiker invites us to look at waste closely, to linger on, to explore it. These last scenes in the novel foreground the materiality of refuse (carving up the horse) in contrast with the luminous immateriality of commodities. Refuse is parceled, distributed, it is unsightly, and needs no promotion as is answers to people's basic needs. The material persistence of trash, the "thingness" of trash, signifies the physicality of history as a material presence. After all, filth is much more ancient and much more enduring than any commodity ever purchased. And thus it becomes a symbol for otherness, unclaimed potentiality, history.

Post-Soviet and South African "consumers" cannot be read as first-world consumers although they build themselves in their image. They complete the seduction of the modernist Benjaminian subject by becoming obsessive shoppers and designer commodities, only to walk away from the logic of commodities altogether. The protagonist of Dukhless disappears into post-soviet postindustrial wilderness; while Tshepo "rediscovers" himself in the slums. In the end of the novel, Tshepo reemerges in Johannesburg, a city considered less cosmopolitan, more "African" and more dangerous. In this selfimposed exile, we find him recovering from his wounds, healing, cautiously optimistic: "I believe in people, in humankind, in personhood. In Hillbrow I live with foreigners, illegal and legal immigrants, what black South Africans call makwere-kwere with derogatory and defiant arrogance. I feel at home with them as they are trying to find home in our country. They are so fragile, so cultured and beauti- 
Alla Ivanchikova,

"Commodity and Waste as National Allegory in Recent South African and Post-Soviet Fiction"

page 9 of 9

CLCWeb: Comparative Literature and Culture 13.4 (2011): <http://docs.lib.purdue.edu/clcweb/vol13/iss4/7>

ful, our foreign guests. In their eyes I feel at home, I see Africa" (454). He finds his home, perhaps temporarily, in exile, among foreigners, migrants, and refugees - people without a home. For him, this awkward community of displaced, disempowered but kind people represents the hope for a better future - one where he would be reduced to neither commodity nor refuse. In the last paragraphs of the novel he expresses a hope that he, his country, and the violence of the past will eventually be redeemed: "perhaps Africa is a late bloomer, not a late starter" (454).

The emergence of writers such as Duiker and Minaev signal the need for an in-depth exploration and critique of the over-inflation of commodity when it enters the hinterlands of global capitalism. Both writers depict their protagonists in their transition from the initial uncritical investment in the logic of consumerism, where they appear primarily as a connoisseur of commodities and brands, to the position of trash deprived of exchange value. What distinguishes Duiker's take on commodity-ascolonialism is the fact that he attempts to provide an alternative to this neurotic identification with the commodity, if only in a form of taking his protagonist permanently out of "circulation." There is a suggestion that Thsepo will heal and discover "real Africa" away from the metropolitan Cape Town. Minaev's writing lacks Duiker's sympathy towards the protagonist and does not provide any viable alternatives; however, his honest and somewhat detached approach invites the reader to disidentify with the protagonist. The narrative of the protagonist's disintegration can be thus viewed as a cautionary tale for the reader and an allegory of the post-socialist condition.

\section{Works Cited}

Bauman, Zigmunt. "Desert Spectacular." The Flâneur. Ed. Kevin Tester. London: Routledge, 1994. 138-58.

Benjamin, Walter. Selected Writings 1938-1940. Ed. Michael Jennings. Cambridge: Harvard UP, 2003.

Benjamin, Walter. The Archades Project. Cambridge: Harvard UP, 1999.

Bessinger, Mike, and Crawford Young. "Introduction: Comparing State Crises across Two Continents." Beyond State Crisis? Postcolonial Africa and Post-Soviet Eurasia in Comparative Perspective. Ed. Mike Bessinger and Crawford Young. Washington: Woodrow Wilson Center, 2002. 3-18.

Bowlby, Rachel. Just Looking: Cosumer Culture in Dreiser, Gissing, and Zola. New York: Methuen, 1985.

Buck-Morss, Susan. The Dialectics of Seeing: Walter Benjamin and the Arcades Project. Cambridge: MIT P, 1989.

Duiker, K. Sello. The Quiet Violence of Dreams. Cape Town: Kwela, 2001.

Eagleton, Terry. "Awakening from Modernity." The Times Literary Supplement (20 February 1987): 194.

Irigaray, Luce. "Commodities among Themselves." The Sex which is not One. By Luce Irigaray. Ithaca: Cornell UP, 1985. 192-98.

Jones, Tim Trengove. "Fiction and the Law: Recent Inscriptions of Gayness in South Africa." Modern Fiction Studies 46.1 (2000): 114-36.

Marx, Karl. Capital: The Critique of Political Economy. New York: Vintage, 1977.

Minaev, Sergey. Dukhless. Povest o nenastoiaschem cheloveke (Douh-Less: The Tale of an Unreal Person). Moscow: Khranitel, 2007.

Nixon, Rob. "Aftermath: South African Literature Today." Transition 72 (1996): 64-77.

Oushakine, Sergei. "The Quantity of Style: Consumption in Post-Soviet Russia." Theory, Culture, and Society 17.5 (2000): 97-120.

Parsons, Deborah. Streetwalking the Metropolis: Women, the City, and Modernity. Oxford: Oxford UP, 2000.

Author's profile: Alla Ivanchikova teaches world literature and critical theory at the University of Alaska Fairbanks. Her interests in research include aspects of globalization and transnational approaches to contemporary literature with particular emphasis on issues of gender, sexuality, and race. Ivanchikova's recent publications include "Flirting with the Law: Queer Culture beyond Transgression," Academic Quarter 3 (2011) and "Sidewalks of Desire: The Invention of Queer Space," The Journal of Contemporary Thought 33 (2011). E-mail: <aivanchikova@alaska.edu> 